\title{
Senecio spp. POISONING OF HORSES IN SOUTHERN BRAZIL ${ }^{1}$
}

\begin{abstract}
Aldo Gava² e Claudio S.L. Barros ${ }^{3}$
ABSTRACT.- Gava A. \& Barros C.S.L. 1997. Senecio spp. poisoning of horses in southern Brazil. Pesquisa Veterinária Brasileira 17(1):36-40. Departamento de Patologia, Universidade Federal de Santa Maria, RS 97119-900, Brazil.

Cases of seneciosis in horses occurring in four farms in the state of Santa Catarina and in another in the state of Rio Grande do Sul, southern Brazil, are reported. S. brasiliensis or S. oxyphyllus or both were detected in four of the five properties. Five horses (one on each property) were necropsied, and tissues for histopathological examination were collected from four horses. Neurological signs, such as depression, ataxia, aimeless walking, circling, head pressing, faulty prehension of food, dysphagia and blindness were consistently observed. Other signs included inappetence, loss of weight, colic, subcutaneous edema, icterus and photodermatitis. At necropsy the livers were firmer and darker than normal and had accentuation of lobular pattern. Edema of the mesentery and ascites were observed in one horse. Main histopathological changes consisted of hepatic chiefly periportal fibrosis, hepatomegalocytosis and biliary hyperplasia. Marked cholestasis and morphological evidence of hepatic encephalopathy were seen respectively in the liver and brain of one of the horses.
\end{abstract}

INDEX TERMS: Poisonous plants, Senecio brasiliensis, S. oxyphyllus, Compositae, diseases of horses, pathology.

SINOPSE.- Intoxicação por Senecio spp. em equinos no sul do Brasil. São relatados casos de seneciose em equinos, em quatro propriedades rurais do estado de Santa Catarina e em uma do Rio Grande do Sul. Em quatro dessas propriedades, Senecio brasiliensis ou $S$. oxyphyllus ou ambos estavam presentes em grandes quantidades. Cinco equinos (um em cada propriedade) foram necropsiados e de quatro necropsias foram colhidos tecidos para exame histológico. Sinais clínicos de distúrbios neurológicos como depressão, ataxia, andar a esmo, torneio, pressão da cabeça contra objetos, dificuldade em apreender os alimentos, disfagia e cegueira foram consistentemente observados. Outros sinais incluíam inapetência, perda de peso, cólica, edema subcutâneo, icterícia e fotodermatite. À necropsia, os fígados estavam mais firmes e escuros e tinham acentuação do padrão lobular. Edema do mesentério e ascite foram observados em um equino. Os principais achados histopatológicos consistiram de fibrose hepá-

\footnotetext{
${ }^{1}$ Accepted for publication on January 14, 1997.

Supported by CNPq, grant \# 404107/88-5.

${ }^{2}$ Laboratório de Anatomia Patológica, Centro de Ciências Agroveteri-nárias, Universidade para o Desenvolvimento de Santa Catarina, Av. Luis de Camões 2090, SC 88520-000, Brazil.

${ }^{3}$ Departamento de Patologia, Universidade Federal de Santa Maria, 97119900 Santa Maria, Rio Grande do Sul, Brazil; bolsista do CNPq (350938/91-1).
}

tica, principalmente periportal, hepatomegalocitose e hiperplasia biliar. Colestase acentuada e evidências morfológicas de encefalopatia hepática foram observadas respectivamente no fígado e cérebro de um dos equinos.

TERMOS DE INDEXAÇÃO: Plantas tóxicas, Senecio brasiliensis, $S$. oxyphyllus, Compositae, doenças de equinos, patologia.

\section{INTRODUCTION}

Poisoning of domestic animals by Senecio spp. and other pyrrolidine alkaloids containing plants is recognized worldwide; cattle and horses are the species more frequently affected (Bull et al. 1968, Elcock \& Oehme 1982). The chronic disease is the usual form of poisoning, clinical signs occurring weeks or months after the plant has been eaten; nervous signs are consistently observed in affected horses and include sleepiness (Ford et al. 1973, Araya \& González 1979, Garret et al. 1984), ataxia and aimless walking (McLintock \& Fell 1953, Fowler 1965, Tennant et al. 1973, Araya \& González 1979, Giles 1983, Gulick et al. 1980, Garret et al. 1984, Pilati 1990), circling (Kingsbury 1964, Fowler 1965, Tennant et al. 1973, Araya \& González 1979, Giles 1983), head pressing (Fowler 1965, Tennant et al. 1973, Giles 1983) and blindness (Tennant et al. 1973, Araya \& González 1979, Giles 1983). Other signs such as inappetence, loss of weight and diarrhea (Ford 1973, Gulick et al. 1980, Garret et al. 1984) or constipation (Fowler 1965), icterus and photodermatitis (McLintock \& Fell 1953, Fowler 1965) are also reported. 
Necropsy findings are primarily those of a chronic hepatic disease. The liver is firmer with accentuation of lobular pattern. Ascites, edema of the mesentery and the gastrointestinal tube can be observed (Araya \& González 1979, Qualls Jr. 1980, Garret et al. 1984, Pilati 1990).

Histologically liver changes include fibrosis, biliary hyperplasia, hepatomegalocytosis and variable degrees of cholestasis (Bull 1968, Tennant et al. 1973, Araya \& González 1979, Qualls Jr. 1980, Garret et al. 1984, Lessard et al. 1986, Pilati 1990).

In Brazil there are some 128 species of Senecio (Matidome \& Ferreira 1966) of which S. brasiliensis, S. cysplatinus, S. selloi, $S$. heterotrichius and $S$. tweedii are causes of heavy losses in cattle in the state of Rio Grande do Sul (Riet-Correa et al. 1994). However, reports of the toxicosis in horses are few (Carvalho \& Maugé 1946, Curial \& Guimarães 1958).

In this paper the occurrence of five outbreaks of Senecio spp. poisoning in horses in southern Brazil is reported.

\section{MATERIALS AND METHODS}

Epidemiological, clinical, gross and histopathological data were collected by the authors through informations from veterinary practitioners. Cases occurred in five properties (A-E) from 1983 to 1994; five horses, one on each property, were necropsied (Table 1). Horses 3 and 5 were euthanatized in advanced stages of illness by intravenous injection of barbiturates; the other horses died naturally. Formalin fixed tissue samples were taken for histologic examination from four horses and included liver, large intestine, skin, spleen, kidney and brain. Advanced post-mortem changes made a proper histopathological evaluation impossible in horse 2 . Formalin fixed tissues from horse 1 were received by the laboratory of one the authors (A.G). The remaining four horses were necropsied by the authors themselves. Sections of tissues were routinely processed for histopathology. Selected liver sections were additionally stained by Masson's trichomic and Gomori's reticulum impregnation for collagen .

\section{RESULTS}

Epidemiology and clinical signs

Data on each occurrence of Senecio poisoning are on Table 1 . Horse 1 received alfalfa hay and a commercial ration of undetermined source. Horses 2, 4 and 5 had always been exclusively grazing at pasture. Horse 3 was at pasture and supplemented with alfalfa hay, rye-grass (Lolium multiflorum), cameroon (Choris gayana) and commercial ration of undetermined source.

\section{Clinical signs}

At Property E, in addition to horse 5, five horses died with similar clinical signs: two 6-9 month old colts, a 3-year old female and two adult mares. Clinical history was not available for horse 1. Similar neurological signs were consistently observed in all the other four necropsied horses and in the five non-necropsied horses that died at Property E. Dullnes, decreased food intake and loss of weight were the initial clinical signs observed in all horses. Horse 3 lost $100 \mathrm{~kg}$ from a total body weight of $550 \mathrm{~kg}$. Consistently, various manifestations of progressive incoordinated gait were observed such as swaying of the hindlimbs (horses 2, 3 and 4), head held down (horses 2, 3 and 5) and crossing of the fore legs (horse 5). Compulsive and aimless walking were noticed in horses 2, 3 and 5, stumbling into objects in its path in horse 5, apparent blindness in horses 2, 3, 4 and 5, and head pressing in horses 2,3 and 4 . Horse 4 had left-sided circling, faulty prehension of food, dysphagia and persistent opened mouth.

Subcutaneous dependant edema of the prepuce and ventral abdomen, nasal mucous discharge, sudoresis, abdominal pain and prolapse of penis were observed in two horses ( 2 and 3). Opacity of the cornea, reddening of the sclera and conjunctiva of both the eyes and polyuria occurred in horse 4 , and jaundice and photodermatitis of unpigmented portions of the forehead, lower limbs and muzzle occurred in horse 5 (Fig. 1). Two other horses in Property E had similar skin lesions.

It was not possible to determine exactly the duration of the clinical course in all horses. In horse 2 and 3 it was estimated to be 30 and 60 days respectively. Death occurred 3 (horse 4) to 15 days (horse 5 and other horses of Property E) after the onset of clinical signs. Except for the incoordinated gait, there was amelioration of clinical signs in horses 2 and 3 within 15 days of the onset of the disease, although the signs recurred with increased intensity within about 20 days.

Table 1. Data on the epidemiology and the five necropsied horses spontaneously poisoned by Senecio spp.

\begin{tabular}{|c|c|c|c|c|c|c|}
\hline $\begin{array}{l}\text { Horse } \\
\text { (Property) }\end{array}$ & Age & Sex & Breed & $\begin{array}{l}\text { Species of } \\
\text { Senecio on } \\
\text { the pasture }\end{array}$ & $\begin{array}{l}\text { Month of } \\
\text { death }\end{array}$ & $\begin{array}{l}\text { Place of } \\
\text { occurrence }\end{array}$ \\
\hline $1(\mathrm{~A})$ & Adult & $\mathrm{m}$ & Thoroubred & $\mathrm{ND}^{\mathrm{a}}$ & ND & Florianópolis, $\mathrm{SC}^{\mathrm{b}}$ \\
\hline 2 (B) & 12 years & $f$ & Mixed & S. brasiliensis & ND & Lages, SC \\
\hline $3(\mathrm{C})$ & 15 years & $\mathrm{m}$ & Percheron & S. brasiliensis & November & Mafra, SC \\
\hline $4(\mathrm{D})$ & 8 months & $\mathrm{f}$ & Mixed & S. brasiliensis & January & Atalanta, SC \\
\hline $5(\mathrm{E})$ & 12 years & f & Mixed & $\begin{array}{l}\text { S. brasiliensis } \\
\text { and S. oxyphyllus }\end{array}$ & January & $\begin{array}{l}\text { Fortaleza dos } \\
\text { Valos, } \text { RS }^{\mathrm{c}}\end{array}$ \\
\hline
\end{tabular}

${ }^{\mathrm{a}} \mathrm{ND}=$ Not determined.
${ }^{\mathrm{b}} \mathrm{SC}=$ Santa Catarina.

${ }^{\mathrm{c}} \mathrm{RS}=$ Rio Grande do Sul. 


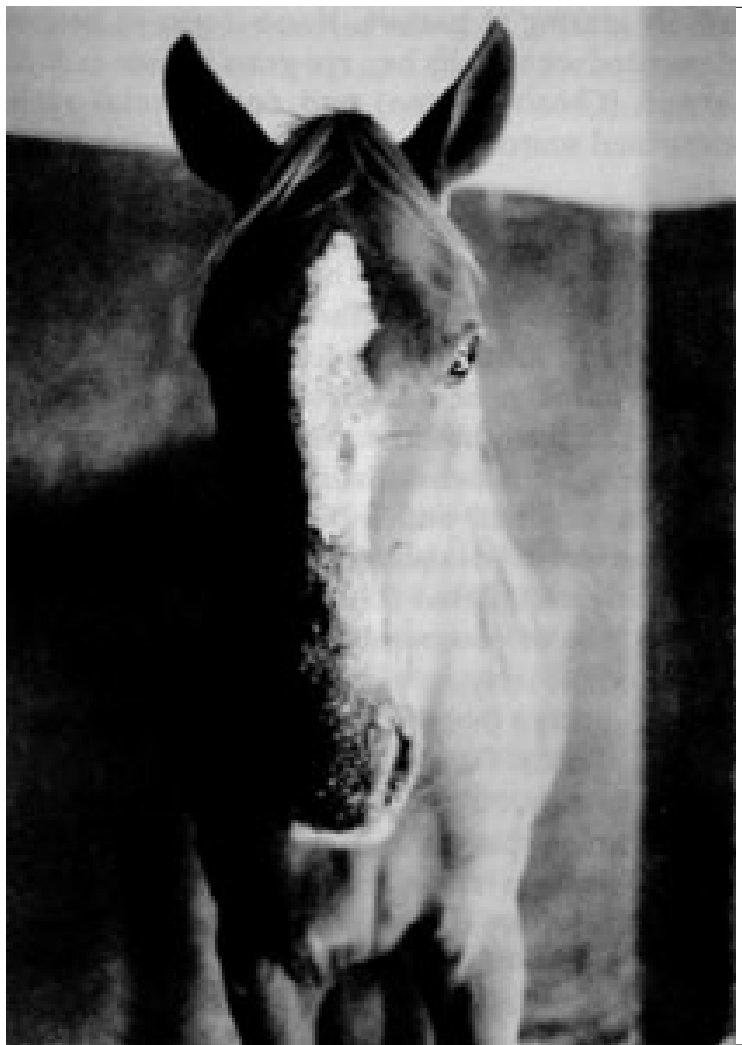

Fig. 1. Photosensitive dermatitis of unpigmented areas of the muzzle and forehead, in Senecio spp. poisoning (Horse 5).

\section{Necropsy findings}

All livers were fibrotic and slightly (horse 5) to moderately (horses 1, 3 and 4) hard and either moderately decreased (horses 1, 3, and 4) or slightly increased (horse 5) in size. All livers had smooth capsular surface except for some capsular fibrous tags, a rather common incidental necropsy finding in livers of horses. Three livers (from horses 1, 4 and 5) were darker than normal. All four had variable degrees of accentuation of the lobular pattern, both in the capsular and cut surfaces, as whitish fine strands of perilobular connective tissue. The livers of horses 1 and 3 had a light orange hue on their cut surface and scattered multifocal whitish foci; the cut surface of the liver from horse 5 had a diffuse olive-green color.

Aspiration pneumonia and petechiation of intestinal serosal surface, marked mesenteric edema and ascites (10 liters) were observed in horse 4 . Horse 5 had crusty scabby lesions of photodermatitis in the unpigmented portions of the fore head, muzzle and lower parts of the four limbs; the mucosa of the large colon and cecum were diffusely and moderately reddened.

\section{Histopathological findings}

Variable degrees of fibrosis, biliary ductal proliferation and marked hepatomegalocytosis were present in all four livers (Fig. 2). Fibrosis was mild and more pronounced on portal triads. Although a low degree of intralobular fibrosis could be seen, none of the horses had fibrosis on the central vein. Biliary ductal proliferation followed the fibrosis pattern and was associated with mononuclear and eosinophilic cellular infiltrates. Ductal proliferation was marked in horse 5 and moderate in the others. Megalocytosis was marked (up to 5 fold the normal size of a hepatocyte) in all livers and was characterized by increased size of both nucleus and cytoplasm, with marked cytoplasmic limits. The voluminous parenchymal cells frequently blocked the sinusoidal lumina. Many of the enlarged hepatocytes had open-faced nuclei (with marginated chromatin) and some had acidophylic globules bounded by a thin basophilic margin. Individual hepatocellular coagulative necrosis and acidophilic intracytoplasmic globules of variable size in hepatocytes were occasionally found. Randomly scattered through the lobule moderated numbers of neutrophil aggregates were seen. Discrete nodules of normal hepatocytes were found among the megalocytes; these nodules occurred with low frequency in horse 5 and moderate to high frequency in horses 1 and 3. Marked intracellular and canalicular bilestasis occurred in horse 5 .

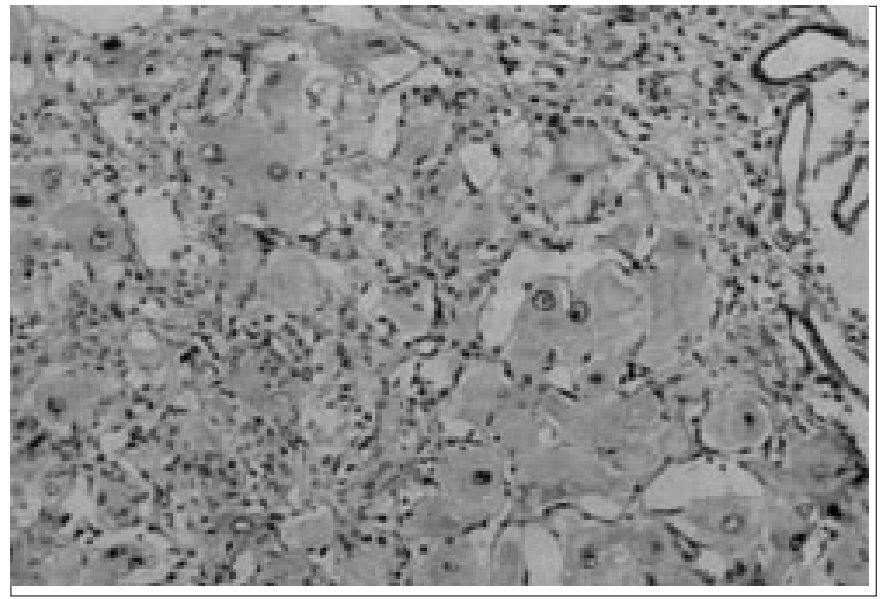

Fig. 2. Liver with mild to moderate fibrosis, marked biliary ductal hyperplasia and megalocytosis, in Senecio spp. poisoning (Horse 3). HE, obj. 6.3.

The skin of the forehead from horse 5 had areas of mild hyperplasia with pseudoepitheliomatous changes in the epidermis. In other areas the epidermis was thin and covered with cellular debris consisting of keratin fragments and dead or degenerated epitheial cells and neutrophils. A small amount of well vascularized, congested granulation tissue was present in the upper portions of the dermis.

Changes in the central nervous system were seen in the brain of horse 5; astrocytes with swollen, open-faced, vesicular nuclei were seen arranged in close pairs or triplets in the telencephalic cortex. These cells were morphologically similar to Alzheimer type II astrocytes. 


\section{DISCUSSION}

A specific clinical diagnosis of Senecio spp. toxicosis in the horse is difficult because of the insidious onset of the clinical signs and because there are many different causes of hepatic failure (Elcock \& Oehme 1982). However, a history of access to these plants, associated with typical gross and histopathological findings (McLintock \& Fell 1953, Fowler 1965, Kingsbury 1964, Bull et al. 1968, Ford 1973, Tennant et al. 1973, Araya \& González 1979, Gulick et al. 1980, Qualls 1980, Garret et al. 1984, Elcock \& Oehme 1982, Gles 1983, Lessard et al. 1986, Pilati 1990) can be diagnostic. The presence of large amounts of $S$. brasiliensis, S. oxyphyllus or both were detected in four of the five properties where the outbreaks occurred. These two species are known to be toxic to livestock and the toxicosis has been experi-mentally reproduced with S. brasiliensis in cattle (Tokarnia \& Döbereiner 1984, Méndez et al. 1990) and horses (Pilati 1990) and also with S. oxyphyllus in cattle (Driemeier \& Barros 1992). The pyrrolizidine alkaloids integerrimine and retrorsine were found in $S$. brasiliensis (Méndez et al. 1990) and retrorsine and ligularizine in $S$. oxyphyllus (Liddel et al. 1992).

Although Senecio spp. poisoning is probably the most important cause of death in cattle in southern Brazil (Barros et al. 1992, Méndez 1993, Riet-Correa et al. 1994), the occurrence of seneciosis in horses is rare in this region. Since the disease has a striking clinical course and typical gross and histopathological findings, it is unlikely that more than a few cases would pass unrecognized. Neither can species resistancy account for the low incidence in horses, since experiments with $S$. brasiliensis indicate that they are similary sensitive as cattle to the toxicosis (Pilati 1990). A possibility is that horses are more selective in their grazing habits or are more often supplemented with concentrate, avoiding long periods of hunger as occurs with cattle.

In this study neurological signs were consistent clinical findings, so seneciosis should be included in the differential diagnosis of diseases of the central nervous system in horses. Although hepatic cirrhosis is the primary chronic lesion caused by Senecio spp., secondary signs of liver failure occur and compose the clinical picture. Thus when enough liver cells are lost or not functional, ammonia is not converted to urea for excretion and hyperammonemia occurs (Hooper 1975). Ammonia is toxic to the central nervous system inducing a state called hepatic encephalopathy. In cases of hepatic encephalopathy, Alzheimer type II astrocytes can be observed in the cortex basal nuclei and hippocampus (Summers et al. 1995). Similar cells were observed in the brain of one horse of this study and also in brains of horses with experimentally induced seneciosis (Qualls 1980, Pilati 1990) and naturally occurring aflatoxicosis (Angsubhakorn et al. 1981). It is important to point out that one author (Hooper 1975) maintains that cells similar to Alzheimer type II astrocytes are also found in brains of normal horses and sheep.

As compared with the liver lesions induced by Senecio spp. in cattle (Tokarnia \& Döbereiner 1986, Barros et al. 1992, Driemeier \& Barros 1992) the hepatic lesions of horses from this study have a milder fibrosis and a more marked hepatomegalocytosis. Other signs of liver failure as edema and photodermatitis were also found in horses of this study.

\section{REFERENCES}

Angsubhakorn S., Poomises P., Romruem K. \& Newberne P.M. 1981. Aflatoxicosis in horses. J.Am.Vet. Med. Assoc. 178:274-278.

Araya O. \& González S. 1979. Intoxicación de caballos con Senecio erraticus. Actual. Vet., B. Aires, 41: 743-745.

Barros C.S.L., Driemeier D., Pilati C., Barros S.S. \& Castilhos L.M.L. 1992. Senecio poisoning in cattle in southern Brazil. Vet. Hum. Toxicol. 34:241246.

Bull L.B., Culvenor C.C.J. \& Dick A.T. 1968. The Pyrrolizidine Alkaloids. Their chemistry, pathogenicity and other biological properties, chap. 9, p. 177186. North Holland Publishing Company, Amsterdam.

Carvalho G.S.T. \& Maugé G.C. 1946. Ação tóxica do “Senecio brasiliensis” Lessing, fam. Compositae. Revta Fac. Med. Vet., São Paulo, 3: 131-136.

Curial O. \& Guimarães J.P. 1958. Cirrose hepática enzoótica no cavalo. Mem. Inst. Oswaldo Cruz 56:635-643 + 5 il.

Driemeier D. \& Barros C.S.L. 1992. Intoxicação experimental por Senecio oxyphyllus (Compositae) em bovinos. Pesq. Vet. Bras. 12:(1):33-42.

Elcock I. \& Oehme F.W. 1982. Senecio poisoning in horses. A summary. Vet. Hum. Toxicol. 24: 122-123.

Ford E.J.H. 1973. The clinical aspects of ragwort poisoning in horses. Vet. Ann. 14: 86-88.

Fowler M.E. 1965. Clinical manifestation of primary hepatic insufficiency in the horse. J. Vet. Med. Assoc. 147:55-64.

Garret B. J., Holtan D.W., Cheeke P.R., Schmitz J.A. \& Rogers Q.R. 1984. Effects of dietery supplementation with butylated hydroxynisole, cysteine and vitamins B on tansy ragwort (Senecio jacobaea) toxicosis in ponies. Am. J.Vet. Res. 45: 459-464.

Giles C.J. 1983. Outbreak of ragwort (Senecio jacobaea) poisoning in horses. Eq. Vet. J. 15: 248-250.

Gulick B.A., Liu I.K.M., Qualls Jr. C.W., Gribble D.,H., \& Rogers Q. R. 1980. Effect of pyrrolizidine alkaloid-induced hepatic disease on plasma amino acid patterns in the horse. Am. J. Vet. Res. 41: 1894-1898.

Hooper P.T. 1975. Spongy degeneration in the central nervous system of domestic animals. Part I. Occurrence and pathogenesis - hepatocerebral disease caused by hyperammonemia. Acta Neuropath. (Berl.) 31: 343-351.

Kingsbury J.M. 1964. Poisonous Plants of the United States and Canada. Prentice Hall, Englewood Cliffs, p. 425-435.

Lessard P., Wilson, W. D., Olander H.J., Rogers Q.R. \& Mendel V.E. 1986. Clinicopathologic study of horses surviving pyrrolizidine alkaloid (Senecio vulgaris) toxicosis. Am. J. Vet. Res. 47: 1776-1780.

Liddell J.R., Stermitz F.R, \& Barros C.S.L. 1992. Pyrrolizidine alkaloids from Senecio oxyphyllus, a Brazilian poisonous plant. Biochem. System. Eco. 20:393.

McLintock J. \& Fell B.F. 1953. A case of acute ragwort poisoning in the horse. Vet. Rec. 65:319-320.

Méndez M.C. 1993. Intoxicação por Senecio spp., cap. 3, p. 43-77. In: RietCorrea F., Méndez M.C. \& Schild A.L. (ed.) Intoxicações por Plantas e Micotoxicoses em Animais Domésticos. Editorial Agropecuária Hemisfério Sur S.R.L., Buenos Aires. 340p.

Méndez M.C., Riet-Correa F., Schild A.L. \& Martz W. 1990. Intoxicação por cinco espécies de Senecio em bovinos e aves. Pesq. Vet. Bras. 10 (2):63-69.

Motidome M. \& Ferreira P.C. 1966. Alcalóides do Senecio brasilienses Less. Revta Fac. Farm. Bioquímica, São Paulo, 4: 13-44.

Pilati C. 1990. Intoxicação experimental por Senecio brasiliensis (Compositae) em equinos. M.Sc. Diss., Universidade Federal de Santa Maria, Santa Maria, RS. 94p. 
Qualls Jr. C.W. 1980. Senecio vulgaris toxicity in the horse. Diss. PhD, Univ. California, Davis. 179p.

Riet-Correa F., Méndez M.C., Barros C.S.L. \& Gava A. 1994. Poisonous plants of Rio Grande do Sul, chap. 3, p.13-18. In: Colegate S.M \& Dorling P.R. (ed.) Plant-Associated Toxins. CAB International, Wallingford. $581 \mathrm{p}$.
Summers B.A, Cummings J.F. \& Lahunta A. 1995. Veterinary Neuro-pathology. Mosby, Baltimore, p. 208-211.

Tennant B., Evans C.D., Schwartz I.W., Gribble D.H. \& Kaneko J.J. 1973. Equine hepatic insufficiency. Vet. Clin. North Am. 3: 279-289.

Tokarnia, C.H. \& Döbereiner J. 1984. Intoxicação experimental por Senecio brasiliensis (Compositae) em bovinos. Pesq. Vet. Bras. 4(1):39-65. 